\title{
Apakah Ekspresi Cinta Memprediksi Perasaan Dicintai? Kajian Bahasa Cinta Pasif dan Aktif
}

\author{
Edwin Adrianta Surijah, Ni Kadek Prema Dewi Sabhariyanti, Supriyadi \\ Program Studi Psikologi, Universitas Dhyana Pura, Bali, Indonesia \\ e-mail: edwin@adrianta.com
}

\begin{abstract}
This research aims to discuss theories of love especially in typology perspective which included current Five Love Languages (FLL) theory. This research also examined whether someone who feels loved based on a certain aspect of FLL would also express love in a similar fashion. FLL scale was divided into passive (felt love) and active (express love) form. 637 participants who were/are in a romantic relationship responded to both scales. Regression analysis examined the contribution from each of active FLL aspect toward passive FLL aspects. The result showed passive FLL was determined by active FLL expression and similar passive-active aspects showed the strongest relationship. The result brought implication to future study and on how to better understand a couple's need to feel loved.
\end{abstract}

Keywords: love, love languages, typology

\begin{abstract}
Abstrak
Penelitian ini ingin membahas teori tentang cinta dalam perspektif tipologi yang di dalamnya meliputi teori Five Love Languages/ Lima Bahasa Cinta (FLL). Penelitian ini ingin menguji apakah seseorang yang merasa dicintai berdasarkan salah satu konsep FLL juga akan menunjukkan perasaan cinta dengan cara yang serupa. Skala FLL dibagi menjadi bentuk pasif (merasa dicintai) dan aktif (menunjukkan cinta) dan diisi oleh 637 partisipan yang pernah/sedang dalam hubungan romantis. Analisis regresi dilakukan untuk menguji masing-masing aspek skala FLL aktif memprediksi aspek-aspek pada skala FLL pasif. Hasil analisis menunjukkan bahasa cinta pasif seseorang ditentukan dari ekspresi aktifnya dan aspek pasif-aktif yang serupa menunjukkan hubungan/ prediksi yang paling kuat. Penelitian ini memberi implikasi pada penelitian selanjutnya maupun cara memahami kebutuhan pasangan untuk merasa dicintai.
\end{abstract}

Kata Kunci: cinta, bahasa cinta, tipologi

\section{Pendahuluan}

Cinta dan relasi romantis merupakan komponen penting kehidupan manusia. Cinta dan relasi romantis membawa dampak bagi kesejahteraan psikologis (Weisskirch, 2017) dan kesehatan manusia (Kiecolt-Glaser \& Wilson, 2017). Cinta sebagai komponen penting kehidupan manusia menjadi topik yang menarik untuk dikaji secara empirik. Sebagai contoh, penelitian mencoba memahami keterkaitan antara proses kognitif intuisi dan perasaan cinta (Grant-Jacob, 2016) atau hubungan antara perasaan cinta dan benci (Jin, Xiang, \& Lei, 2017). Penelitian kali ini mengkaji cinta dari sudut pandang tipologi.
Prinsip kecocokan pasangan seringkali dianggap sebagai salah satu kriteria kesuksesan suatu relasi. Penelitian menunjukkan bahwa kecocokan antara pasangan menjadi salah satu indikator penting suatu hubungan (Gaunt, 2006;

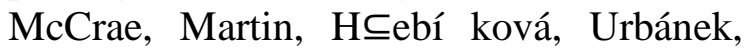
Boomsma, Willemsen, \& Costa 2008; Wang, Kim, \& Boerner, 2018). Oleh karena itu, banyak muncul artikel populer yang membahas mengenai tipe-tipe cinta untuk membantu pasangan memahami atau mengenal pengalaman dalam relasi mereka (Burton, 2017; Tartakovsky, 2015). Dalam ranah studi empiris, penelitian juga mengkaji tipe-tipe cinta (Gana, Saada, \& Untas, 2013) atau aspek psikologis yang 
dapat memperkaya pemahaman mengenai kecocokan pasangan (Großmann, Hottung, \& Krohn-Grimberghe, 2019).

Salah satu konsep yang populer dan dikenal luas adalah gagasan Chapman (dalam Surijah \& Sari, 2018; Surijah \& Septiarly, 2016) mengenai lima bahasa cinta atau five love languages (FLL). Chapman mengatakan bahwa ada lima tipe bahasa cinta yang menjadi indikator hal-hal yang membuat individu merasa dicintai. Saat individu merasa dicintai, Chapman meyakini kualitas hubungan antara individu dan significant others tersebut akan meningkat. Konsep Chapman ini juga tidak terbatas pada hubungan antara pasangan secara romantis namun juga pada bentuk relasi lain seperti orang tua dan anak. Sebelum mengulas lebih dalam mengenai konsep bahasa cinta, penulis hendak mengulas terlebih dahulu perspektif "tipe" dalam kajian mengenai cinta untuk dapat meletakkan perbedaan bahasa cinta dibandingkan konsep-konsep cinta yang telah ada sebelumnya.

\section{Konsep Cinta dalam Perspektif Tipologi}

Teori klasik Jung (1971) yang menempatkan kepribadian dalam perspektif tipologi membawa dampak signifikan dalam kancah penelitian Psikologi. Secara lebih spesifik, dalam kajian terkait konsep cinta, banyak peneliti yang berupaya memahami cinta dalam pandangan tipologi tersebut. Berbagai skala psikologi telah diciptakan untuk mengukur cinta dalam berbagai tipe dan dimensi (Hendrick \& Hendrick, 1989).

Salah satu peneliti awal yang membahas tentang cinta dalam perspektif tipologi ini adalah Rubin (1970). Rubin memberi kritik tentang sedikitnya penelitian terhadap area "cinta" di tengah maraknya penelitian terkait ketertarikan interpersonal. Hal ini mengakibatkan dangkalnya pemahaman terhadap konsep cinta. Rubin kemudian menyusun alat ukur yang terdiri dari tiga belas butir yang mengukur "loving" (contoh butir: Saya akan melakukan apapun untuk___ dan tiga belas butir yang mengukur "liking" (contoh butir: Saya merasa adalah orang yang cerdas). Hal ini bertujuan untuk menunjukkan bahwa cinta adalah suatu konstruk terpisah. Hasil penelitian Rubin menunjukkan adanya perbedaan antara 'loving' dan 'liking' serta adanya kemungkinan bentuk-bentuk cinta yang lebih kompleks.

Penelitian Rubin (1970) berhasil menunjukkan konsep yang unitary mengenai cinta. Peneliti berikutnya Lee (1977) mendalami tipologi cinta dan menemukan bahwa konsep cinta dapat terbagi menjadi beberapa sub-aspek. Tipe yang pertama adalah Eros yaitu cinta yang menggebu dan penuh hasrat. Tipe yang kedua adalah Ludus yakni cinta yang kompetitif dan memandang hubungan sebagai permainan yang harus dimenangkan. Tipe ketiga, Storge adalah tipe cinta yang tumbuh dari persahabatan maupun minat yang serupa. Tipe keempat adalah Pragma yang memandang hubungan dari sisi praktis (pragmatis) untuk mencapai tujuan bersama. Kelima, Mania merupakan tipe cinta yang obsesif. Terakhir, Agape adalah tipe cinta yang didasari oleh komitmen, selflessness, dan kemauan untuk berkorban.

Teori Lee tersebut kemudian dikembangkan menjadi alat ukur (Hendrick \& Hendrick, 1986). Nama dari skala ini adalah Love Attitudes Scale. Skala yang dikembangkan tersebut terdiri dari 42 butir yang mengukur enam sub-aspek dari teori cinta tersebut (masing-masing aspek diwakili oleh tujuh butir). Ada pula versi pendek (short form) dari skala ini dengan tiap aspek diukur oleh tiga butir saja.

Beberapa penelitian terdahulu telah menelusuri hubungan antara konsep cinta yang dikemukakan oleh Lee tersebut dengan variabel lain. Salah satu contohnya, penelitian menemukan bahwa love attitudes tipe storge memiliki asosiasi dengan penilaian positif perempuan terhadap pujian yang diberikan laki-laki terhadap benda 
material (Gao, Gao, Xu, Zheng, Ma, Luo, \& Kendrick, 2017). Maksudnya, perempuan dengan tipe storge menghargai pria yang memuji barang-barang yang dimiliki oleh perempuan tersebut. Penelitian juga menunjukkan asosiasi love styles antara eros dan sikap positif maupun ludus dan sikap negatif terhadap hewan peliharaan (Guthrie, Marshall, Hendrick, Hendrick, \& Logue, 2018).

Teori cinta juga tidak lepas dari gagasan Sternberg mengenai triangular theory of love (1986). Menurutnya, cinta memiliki tiga komponen yaitu: 1) intimacy, perasaan kedekatan, keterhubungan, dan keterikatan dalam relasi romantis; 2) passion, berkaitan dengan hasrat dan dorongan seksual; dan 3) commitment, keputusan untuk mencintai seseorang dan menjaga perasaan tersebut. Ketiga komponen tersebut saling berinteraksi satu sama lain dan membentuk variasi pengalaman cinta.

Gagasan Sternberg ini kemudian dituangkan dalam bentuk skala pengukuran. Beberapa penelitian di masa lampau mencoba melakukan validasi terhadap skala/ konsep tersebut (Askarpour \& Mohammadipour, 2016; Sternberg, 1997). Alat ukur ini juga menjadi variabel kriteria untuk pengujian Love Attitudes Scale (Levy \& Davis, 1988). Eros dan agape berkaitan erat dengan ketiga aspek cinta Sternberg (intimacy, passion, dan commitment). Akan tetapi storge dan pragma tidak memiliki hubungan signifikan dengan aspek cinta Sternberg. Dalam ranah keilmuan Sastra, teori Sternberg juga dijadikan acuan untuk memahami proses 'cinta' yang dialami oleh karakter dalam novel (Unk, 2017).

Tipologi ini memberi dampak besar dalam penelitian terkait cinta yang tergambar dari munculnya penelitian serupa yang memiliki klasifikasi cinta yang mirip dengan tipologi Sternberg tersebut. Contohnya adalah konstruk love attitudes atau cara pandang seseorang terhadap cinta atau relasi intim (Zeng, Pan, Zhou, Yu, \& Liu, 2016). Love attitudes memiliki empat tipe: 1) game players (mirip dengan ludus), rational lovers (mirip dengan pragma), 3) emotional lovers (mirip dengan eros), dan 4) absence lovers. Penelitian lain juga menelusuri sikap terhadap cinta dan keyakinan seseorang menjalani relasi intim (Yang, Mak, Ho, \& Chidgey, 2017).

Dalam perspektif Linguistik, ada empat belas bentuk cinta (Lomas, 2018). Tipe cinta ini tidak terbatas pada perasaan intim antara seseorang terhadap orang lain. Tipe cinta yang tidak termasuk ke dalam relasi interpersonal adalah: 1) Meraki (perasaan cinta terhadap suatu pengalaman seperti berjalan kaki atau bersepeda), 2) Eros (perasaan cinta terhadap suatu objek seperti barang atau konsep tertentu), dan 3) Chöros (perasaan cinta terhadap suatu tempat tertentu). Kemudian, tipe cinta yang terhubung dengan orang lain adalah: 1) Philia (perasaan cinta dalam wujud persahabatan), 2) Philautia (perasaan cinta terhadap diri sendiri), dan 3) Storgē (perasaan cinta dalam wujud kekeluargaan). Setelah itu, tipe cinta yang berkaitan dengan relasi romantis adalah: 1) Epithymia (perasaan cinta berdasarkan hasrat dan daya tarik fisik), 2) Paixnidi (perasaan cinta dalam bentuk permainan/ play), 3) Mania (perasaan cinta yang diikuti dengan rasa obsesif/ kepemilikan), 4) Prâgma (perasaan cinta dalam wujud komitmen dan didasarkan alasan pragmatis), dan 5) Anánke (perasaan cinta yang sangat mendalam). Terakhir, ada pula tipe cinta yang bersifat sekunder di luar perasaan yang sudah diterangkan sebelumnya yaitu: 1) Agápe (perasaan cinta atas dasar kemanusiaan seperti perilaku amal), 2) Koinōnía (perasaan cinta atas dasar koneksi singkat yang dijalin secara interpersonal/ fleeting moment), 3) Sébomai (perasaan cinta atas dasar kekaguman). Perspektif ini secara lengkap merangkum dan melakukan klasifikasi terhadap tipetipe pengalaman/ perasaan cinta baik yang telah diteliti sebelumnya atau hasil amatan dari kajian lexical. 
Salah satu variabel yang seringkali diteliti dalam konsep relasi romantis adalah adult attachment styles (Simpson \& Rholes, 2017). Konsep ini awal mulanya didasarkan pada gaya kelekatan pada anak-anak namun diadaptasi dalam bentuk skala pengukuran gaya kelekatan pada konteks relasi romantis orang dewasa (Hazan \& Shaver, 1987). Tipe-tipe kelekatan tersebut adalah 1) secure attachment (individu merasa nyaman berada dekat dengan orang lain), 2) avoidant attachment (kesulitan untuk dekat dan mempercayai orang lain), dan 3) anxious/ ambivalent attachment (kecemasan ditinggalkan oleh orang lain). Konsep ini kemudian diperbaharui oleh Bartholomew (1990) menjadi empat tipe kelekatan (secure, preoccupied, fearful, dan dismissing-avoidant).

Gaya kelekatan yang aman (secure) dalam penelitian telah menunjukkan hubungan dengan berbagai macam variabel seperti pola penggunaan media sosial, kepuasan di tempat kerja, kepuasan relasi romantis, dan pengelolaan stres yang baik. Kelekatan yang insecure memiliki asosiasi dengan penggunaan media sosial yang tidak sehat dan intensif (D'Arienzo, Boursier, \& Griffiths, 2019). Individu yang memiliki kelekatan yang menghindar (avoidance) berhubungan dengan rendahnya kepuasan kerja (Reizer, 2015). Secure attachment juga berkorelasi dengan kesehatan mental. Kelekatan yang insecure lebih rentan dengan gejala-gejala kecemasan atau depresi (Surcinelli, Rossi, Montebarocci, \& Baldaro, 2010) serta gejala kecemasan sosial (Read, Clard, Rock, \& Coventry, 2018).

Ada pula konsep tipologi cinta berdasarkan cinta yang tidak berbalas (unrequited love). Tipe cinta ini memiliki lima aspek atau bentuk: 1) perasaan suka terhadap seseorang yang tidak tersedia (misalnya bintang film), 2) perasaan suka terhadap seseorang yang dekat, 3) mengejar seseorang (misal secara aktif mengajak bertemu), 4) mengharapkan pasangan dari masa lalu, dan 5) relasi yang tidak berimbang (Bringle, Winnick, \& Rydell, 2013). Bentuk cinta ini secara khusus menunjukkan tipe-tipe cinta yang tidak berujung pada relasi yang sehat dan membawa dampak negatif.

Keseluruhan tipe yang telah dibahas sebelumnya menunjukkan bentuk-bentuk kondisi suatu hubungan maupun perspektif seseorang terhadap suatu hubungan. Contohnya, suatu hubungan dapat dimasukkan ke dalam kondisi yang penuh 'hasrat' (passionate) atau sebaliknya hanya berupa komitmen saja. Cara pandang terhadap hubungan juga menunjukkan apakah seseorang merasa relasi romantis hanya dari sudut pandang pragmatis (misal untuk mendapat keturunan) atau kompetitif (permainan). Teori Bahasa Cinta menunjukkan perspektif yang berbeda dari tipologi teori cinta sebelumnya karena Bahasa Cinta mengungkapkan kebutuhan dan perasaan seseorang dari perlakuan pasangannya.

\section{Five Love Languages}

Chapman (2010) berdasarkan pengalamannya sebagai konselor menemukan bahwa ada lima hal utama yang membuat seseorang merasa dicintai. Ketika seseorang merasa dicintai, ia akan berfungsi dengan lebih baik dan berkontribusi pada pengalaman yang lebih positif di dalam relasi tersebut. Lima faktor yang membuat seseorang merasa dicintai adalah: 1) mendapatkan pujian (words of affirmation), 2) menghabiskan waktu bersama pasangan (quality time), 3) mendapatkan bantuan dari pasangan (acts of service), 4) memperoleh hadiah (receiving gift), dan 5) menerima sentuhan fisik (physical touch).

Konsep Chapman ini berbeda dengan teori-teori cinta yang telah dipaparkan sebelumnya. Misalnya, Love Attitudes Scale (Hendrick \& Hendrick, 1986) mengukur kondisi (state) relasi yang sedang dijalani. Bahasa cinta (FLL) mengukur kebutuhan yang dirasakan oleh seseorang terhadap pasangannya. Oleh 
karena itu, kajian terhadap bahasa cinta menjadi menarik dan penting untuk dilakukan sehingga pasangan dapat memiliki gambaran kebutuhan yang dimiliki oleh seseorang dalam suatu relasi.

Salah satu sumber bukti empiris adalah konvergensi hubungan antara dua variabel yang terkait (Brown, 2009). Beberapa penelitian telah dilakukan sebelumnya terhadap bahasa cinta yang menguji kesahihan konsep ini (Cook, Pasley, Pellarin, Medow, Baltz, \& Buhman-Wiggs, 2013; Egbert \& Polk, 2006; Polk \& Egbert, 2013). Di Indonesia, sebagian besar penelitian baru melakukan uji konsistensi internal melalui analisis faktor dan hasil penelitian belum menunjukkan sumber bukti yang mendukung gagasan awal Chapman (Surijah \& Sari, 2018; Surijah \& Septiarly, 2016). Sebagai contoh, Surijah dan Kirana (in press) melakukan analisis faktor dan menemukan bahwa lima faktor bahasa cinta yang menjadi hipotesis penelitian tidak memenuhi model fit. Oleh karena itu, penelitian ini hendak mengkaji bahasa cinta dengan sumber bukti empiris selain konsistensi internal yang telah dilakukan sebelumnya.

Studi kali ini mencoba menemukan hubungan antara perasaan dicintai seseorang dan cara seseorang menunjukkan perasaannya. Pertanyaan yang ingin dijawab adalah apakah seseorang yang merasa dicintai dengan tipe bahasa cinta tertentu juga akan memiliki cara mengekspresikan cinta dengan tipe yang serupa. Penelitian ini kemudian membagi dua konsep Bahasa Cinta dan melakukan modifikasi penulisan butir pada skala Bahasa Cinta (Egbert \& Polk, 2006). Perasaan dicintai disebut juga sebagai Bahasa Cinta pasif (kemudian disingkat menjadi skala FLL pasif) sementara ekspresi cinta disebut dengan Bahasa Cinta aktif (skala FLL aktif). Contoh bentuk aktif adalah seseorang menunjukkan rasa cinta dengan sentuhan fisik atau memberi hadiah.

Hipotesis penelitian ini adalah (1) aspek-aspek pada skala FLL Pasif berkorelasi dengan skala FLL aktif dan (2) aspek pada skala FLL pasif akan berkorelasi paling kuat dengan pasangan skala FLL aktif yang sama. Misalnya, aspek words of affirmation pada skala FLL pasif akan berkorelasi paling kuat dengan aspek words of affirmation pada skala FLL aktif. Hipotesis selanjutnya adalah (3) aspek-aspek FLL pasif akan diprediksi secara signifikan oleh aspek FLL aktif yang sama misalnya words of affirmation aktif menentukan words of affirmation pasif.

\section{Metode Penelitian}

Penelitian ini menggunakan pendekatan kuantitatif dengan jenis korelasional, yang melibatkan dua variabel yaitu bahasa cinta pasif dan bahasa cinta aktif. Penelitian ini melanjutkan/ mengembangkan penelitian terdahulu (Surijah \& Septiarly, 2016). Penelitian tersebut meneliti di suatu universitas dengan melibatkan 400 partisipan. Untuk meningkatkan akurasi hasil penelitian, perhitungan jumlah sampel perlu menjadi perhatian. Pada beberapa kasus, penambahan jumlah sampel dapat meningkatkan kualitas hasil temuan (Martínez-Mesa, González-Chica, Bastos, Bonamigo, \& Duquia, 2014). Oleh karena itu, penulis mengunjungi dua universitas sebagai tempat pelaksanaan pengambilan data. Salah satu dari universitas tersebut merupakan tempat yang sama dengan penelitian sebelumnya.

Populasi di masing-masing universitas adalah 1.845 dan 9.355 mahasiswa. Penulis menggunakan Sample Size Calculator 1.0.3.10 dengan selang kepercayaan 5\% dan confidence level 95\%. Perhitungan sampel untuk masing-masing universitas adalah 318 dan 369 partisipan. Penulis kemudian melakukan quota sampling dengan cara menyebarkan kuesioner ke masing-masing universitas hingga memenuhi jumlah sampel yang dibutuhkan. Total partisipan yang menjadi sampel penelitian adalah 687 mahasiswa (309 lakilaki dan 378 perempuan). Rentang usia partisipan adalah 17 hingga 40 tahun 


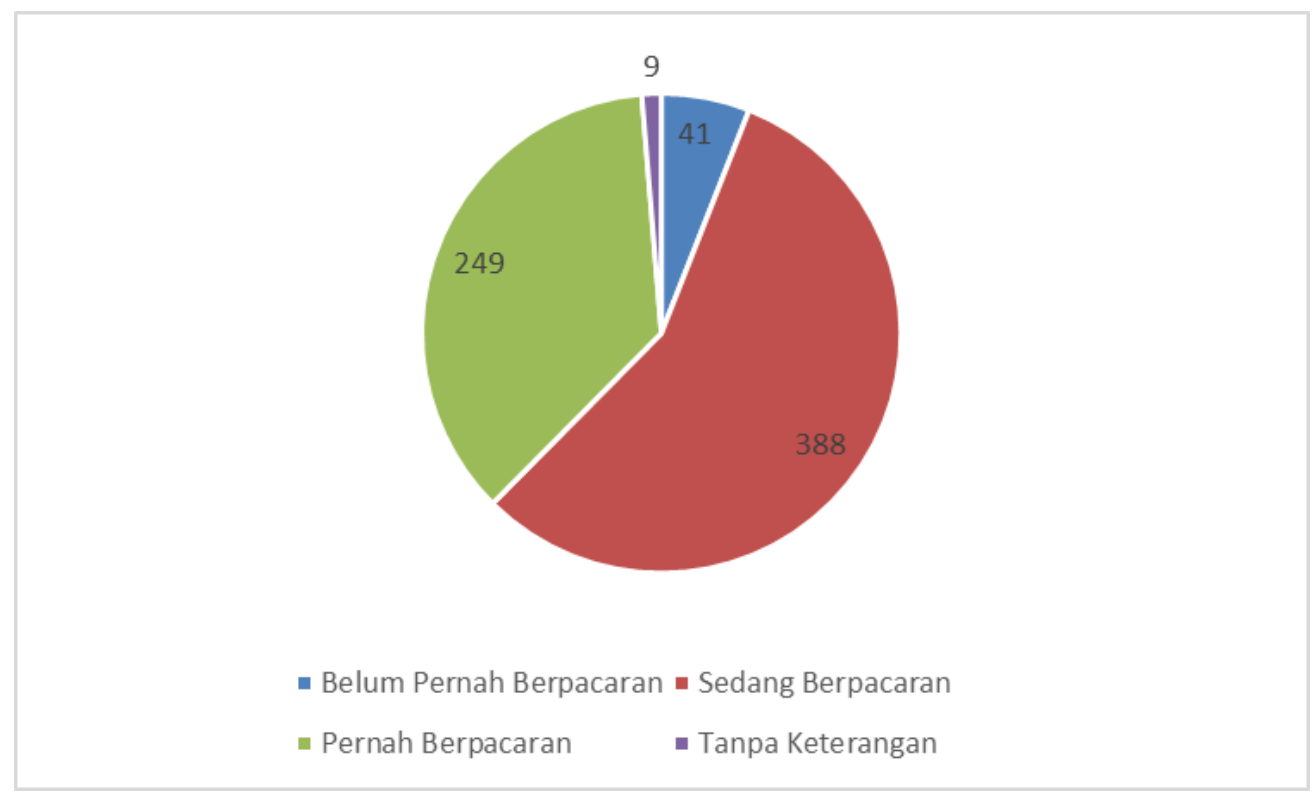

Gambar 1. Status hubungan yang sedang dijalani partisipan

dengan mayoritas partisipan berusia 19-20 tahun (400 orang atau 58.22\%).

Dalam kaitannya dengan topik penelitian yang berkaitan dengan relasi intim/ romantis, penulis meminta kepada partisipan untuk membayangkan relasi yang sedang atau pernah dijalani. Bagi yang belum pernah memiliki pasangan, penulis meminta mereka membayangkan perlakuan apa yang jika dilakukan oleh pasangan membuat mereka merasa dicintai. Berdasarkan status hubungan partisipan sebagaimana disajikan pada gambar 1, hanya 41 partisipan yang belum pernah berpacaran. Sebanyk 637 partisipan sedang atau pernah menjalani hubungan romantis dan 9 partisipan tidak memberikan keterangan status. Hal ini berarti sebagian besar responden memiliki pengalaman atau konsep yang berkaitan dengan relasi romantis atau intim.

Skala pengukuran menggunakan skala yang diadaptasi dari Polk dan Egbert (2013). Penulis telah meminta izin sebelumnya untuk penggunaan alat ukur tersebut dan telah dipublikasikan pada penelitian yang lalu (Surijah \& Kirana, in press). Alat ukur terdiri dari 21 butir yang mengukur lima bahasa cinta. Responden terlebih dahulu membaca instruksi: Saya cenderung merasa dicintai ketika dan diikuti dengan butir-butir pernyataan. Pilihan responden bergerak dari 1 (Tidak merasa dicintai) sampai dengan 10 (Merasa dicintai). Penulis melabeli skala ini sebagai skala bahasa cinta bentuk pasif (FLL Pasif).

Penelitian ini juga hendak mengukur bagaimana individu mengekspresikan perasaan cintanya kepada pasangan. Oleh karena itu, penulis mengubah skala bentuk pasif ke dalam bentuk aktif sama seperti yang dilakukan oleh Polk dan Egbert (2013). Kalimat instruksi diubah menjadi: Saya cenderung untuk mengungkapkan perasaan saya kepada pasangan saya dengan cara. Pilihan respon juga diubah menjadi 1 (Sangat Tidak Sesuai) hingga 10 (Sangat Sesuai). Skala ini disebut sebagai skala bahasa cinta bentuk aktif (FLL Aktif).

Penulis melakukan uji coba alat ukur kepada 60 responden mahasiswa secara insidentil di suatu perguruan tinggi yang berbeda dengan kancah penelitian. Pengujian yang dilakukan adalah uji konsistensi dengan menggunakan Cronbach alpha. Hasil pengujian menunjukkan keseluruhan aspek pada masing-masing skala memiliki nilai koefisien alpha $>.700$ sehingga skala 
dikatakan ajeg untuk dipakai dalam penelitian ini.

Tabel 1

Pengujian Keajegan Skala FLL Pasif dan Aktif

\begin{tabular}{lccc}
\hline \multicolumn{1}{c}{ Aspek } & $\begin{array}{c}\alpha-\text { FLL } \\
\text { Pasif }\end{array}$ & $\begin{array}{c}\alpha-\text { FLL } \\
\text { Aktif }\end{array}$ & $\begin{array}{c}\text { Jumlah } \\
\text { Butir }\end{array}$ \\
\hline Words of & .903 & .902 & 5 \\
affirmation & & & \\
Quality time & .861 & .891 & 4 \\
Acts of service & .752 & .833 & 3 \\
Receiving gifts & .823 & .866 & 4 \\
Physical touch & .913 & .907 & 4 \\
\hline
\end{tabular}

Catatan: $\alpha=$ koefisien alpha

Penelitian hendak menguji hubungan antar aspek di antara kedua variabel. Digunakan simple correlation untuk menguji hubungan tersebut. Selanjutnya dengan model analisis regresi sederhana (Enter), FLL pasif akan menjadi endogenous variable dan FLL aktif akan menjadi exogenous variable.

\section{Hasil Penelitian dan Pembahasan}

\section{Hasil Penelitian}

Hasil pengukuran deskriptif untuk masing-masing aspek pada skala bahasa cinta disajikan pada tabel 2 .

Tabel 2

Data Deskriptif Pengukuran

\begin{tabular}{lcc}
\hline \multicolumn{1}{c}{ Skala FLL/Aspek } & Mean & SD \\
\hline Pasif & & \\
Words of affirmation (WOA) & 38.0437 & 9.16123 \\
Quality time (QT) & 32.2082 & 7.46705 \\
Acts of service (AOS) & 25.4279 & 9.06409 \\
Receiving gift (RG) & 27.2431 & 8.22926 \\
Physical touch (PT) & 29.4614 & 8.81464 \\
Aktif & & \\
Words of affirmation (WOA) & 37.2271 & 10.23062 \\
Quality time (QT) & 31.6798 & 7.51515 \\
Acts of service (AOS) & 24.4352 & 9.12793 \\
Receiving gift (RG) & 26.5648 & 8.42847 \\
Physical touch (PT) & 29.3988 & 9.26267 \\
\hline
\end{tabular}

Hasil pengujian korelasi dengan teknik Pearson tertera pada tabel 3. Seluruh aspek pada skala FLL Pasif berkorelasi signifikan dengan semua aspek pada skala FLL Aktif $(\mathrm{p}<.01)$. Akan tetapi, besaran koefisien korelasi berbeda-beda pada masing-masing pasangan aspek uji korelasi. Untuk menjawab hipotesis penelitian, penulis kemudian mencermati pada pasangan aspek yang mana koefisien korelasi paling kuat dibandingkan dengan pasangan aspek yang lainnya.

Aspek words of affirmation pada skala FLL Pasif -berikutnya ditulis words of affirmation (Pasif)- berkorelasi paling tinggi dengan aspek words of affirmation pada skala FLL Aktif $(\mathrm{r}=.708)$. Namun aspek ini juga berkorelasi kuat dengan physical touch (Pasif) ( $\mathrm{r}=.702)$. Aspek quality time (Pasif) berkorelasi paling kuat dengan quality time (Aktif) ( $\mathrm{r}=.748)$. acts of service (Pasif) berkorelasi paling kuat justru dengan receiving gift (Pasif) $(\mathrm{r}=.697)$. Namun, di antara besaran korelasi dengan aspek skala FLL Aktif, acts of service (Pasif) hanya berkorelasi dengan acts of service (Aktif) sebesar .581. Receiving gift (Pasif) berkorelasi paling kuat dengan receiving gift (Aktif) ( $\mathrm{r}=.674$ ). Physical touch (Pasif) memiliki korelasi paling kuat dengan physical touch (Aktif) $(\mathrm{r}=.834)$ dan jauh lebih kuat dibandingkan dengan korelasi terhadap aspek-aspek yang lain.

Hasil analisis regresi menunjukkan bahwa aspek bahasa cinta pada skala pasif ditentukan oleh aspek pada skala bahasa cinta aktif. Akan tetapi, aspek yang serupa menjadi prediktor terbesar contohnya aspek PT Pasif ditentukan oleh WOA Aktif, QT Aktif, dan PT Aktif $(\mathrm{F}(5)=326.771, p<$ .05) namun PT Aktif merupakan prediktor terbesar $(\mathrm{b}=.713 ; \mathrm{t}(686)=21.032), p<$ $.01)$. Hal ini senada dengan hasil korelasi pada tabel 3 bahwa aspek-aspek yang serupa pada skala pasif dan aktif menunjukkan koefisien korelasi yang paling kuat. 
Tabel 3

Korelasi Antar Aspek pada Kedua Skala Bahasa Cinta

\begin{tabular}{|c|c|c|c|c|c|c|c|c|c|c|}
\hline & 1 & 2 & 3 & 4 & 5 & 6 & 7 & 8 & 9 & 10 \\
\hline 1. WOA Pasif & 1 & .550 & .441 & .614 & .702 & .708 & .492 & .385 & .506 & .583 \\
\hline 2. QT Pasif & & 1 & .544 & .665 & .621 & .388 & .748 & .407 & .482 & .505 \\
\hline 3. AOS Pasif & & & 1 & 697 & .532 & .329 & .444 & .581 & .515 & .429 \\
\hline 4. RG Pasif & & & & 1 & .661 & .460 & .560 & .531 & .674 & .524 \\
\hline 5. PT Pasif & & & & & 1 & .638 & .593 & .500 & .592 & .834 \\
\hline 6. WOA Aktif & & & & & & 1 & .543 & .475 & .616 & .712 \\
\hline 7. QT Aktif & & & & & & & 1 & .537 & .637 & .640 \\
\hline 8. AOS Aktif & & & & & & & & 1 & .727 & .540 \\
\hline 9. RG Aktif & & & & & & & & & 1 & .658 \\
\hline 10. PT Aktif & & & & & & & & & & 1 \\
\hline
\end{tabular}

Tabel 4

Analisis Regresi Skala FLL Pasif dan Aktif

\begin{tabular}{lcc}
\hline & Adjusted $R$ square & Equation \\
\hline WOA Pasif & .519 & $11.550+14.392 \mathrm{WOA}^{*}+2.933 \mathrm{QT} *-0.652 \mathrm{AOS}+0.917 \mathrm{RG}+2.209 \mathrm{PT} *$ \\
QT Pasif & .559 & $9.071-0.072 \mathrm{WOA}+20.309 \mathrm{QT}^{*}+0.004 \mathrm{AOS}+0.117 \mathrm{RG}+2.099 \mathrm{PT} *$ \\
AOS Pasif & .368 & $6.983-1.839 \mathrm{WOA}+2.875 \mathrm{QT}^{*}+9.141 \mathrm{AOS} *+2.236 \mathrm{RG}^{*}+2.235 \mathrm{PT}^{*}$ \\
RG Pasif & .482 & $5.654-0.223 \mathrm{WOA}^{*}+4.923 \mathrm{QT}^{*}+1.204 \mathrm{AOS}+10.008 \mathrm{RG}^{*}+1.515 \mathrm{PT}$ \\
PT Pasif & .704 & $3.450+2.236 \mathrm{WOA}^{*}+2.592 \mathrm{QT}^{*}+1.264 \mathrm{AOS}+0.100 \mathrm{RG}+21.032 \mathrm{PT} *$ \\
\hline
\end{tabular}

Catatan. Singkatan pada bagian equation mewakili aspek pada skala aktif dan tanda (*) menunjukkan aspek yang menjadi prediktor signifikan $(p<.05)$.

\section{Pembahasan}

Pada umumnya, konsep yang terkait akan cenderung menunjukkan pola interkorelasi di antara aspek-aspek penyusun konsep tersebut. Sebagai contoh, penelitian Gosling, Rentfrow, dan Swann Jr. (2003) melakukan uji korelasi antara dua alat ukur kepribadian big five. Hasil uji menunjukkan kelima aspek saling berkorelasi di antara kedua alat ukur. Alat ukur kepribadian dengan konstruk berbeda juga saling berkorelasi misalnya antara Single Item Measures of Personality dan Big Five Inventory (Spörrle \& Bekk, 2014). Hasil penelitian ini menunjukkan masingmasing aspek dalam skala Bahasa Cinta saling berkorelasi secara signifikan $(p<$ .01) dan memiliki arah korelasi yang positif. Hasil tersebut erat kaitannya dengan kedekatan konsep antara bentuk pasif dan aktif skala Bahasa Cinta seperti yang ditunjukkan pada penelitian terkait pengukuran skala kepribadian.

Analisis regresi secara umum juga menunjukkan bahwa masing-masing aspek pada skala FLL pasif ditentukan oleh satu atau lebih aspek pada skala FLL aktif namun aspek yang serupa menjadi prediktor yang paling kuat. Hal ini berarti seseorang memiliki kebutuhan untuk merasa dicintai dan orang tersebut akan menunjukkan dengan cara yang sama ia mengekspresikan rasa cintanya. Cinta merupakan suatu bentuk perasaan yang dapat dikendalikan (Langeslag \& van Strien, 2016). Artinya, ekspresi cinta seseorang merupakan kendali sadar ekspresi dirinya. Temuan penelitian ini menjadi bukti empiris dalam upaya memahami perilaku cinta pasangan bahwa dengan mengenali pola perilaku pasangan, seseorang dapat pula memahami kebutuhan yang ada dalam diri pasangannya tersebut. 
Hasil penelitian ini mendukung gagasan awal penelitian tentang cinta dan relasi romantis dalam perspektif tipologi bahwa kecocokan pasangan menjadi faktor yang penting. Penelitian ini dapat membantu seseorang memahami pasangan dan menilai kecocokan dari ekspresi cinta dan kebutuhan merasa dicintai yang dimiliki. Pasangan yang memiliki kemiripan (compatible) satu sama lain berkorelasi positif dengan kepuasan hubungan (Saggino, Martino, Balsamo, Carlucci, Ebisch, Innamorati, Picconi, Romanelli, Sergi, \& Tomassi, 2016; Wilson $\&$ Cousins, 2003). Kajian bahasa cinta di masa mendatang perlu memerhitungkan kecocokan tipe bahasa cinta dan konsekuensinya terhadap kualitas hubungan romantis.

Cinta selain membawa dampak positif juga dapat membawa dampak negatif. Saat kebutuhan seseorang terpenuhi, cinta dapat membuat seseorang mengatasi permasalahan adaptif dirinya. Sebaliknya saat kebutuhan akan cinta tidak terpenuhi, hal ini dapat membawa permasalahan psikologis terhadap kesehatan mental hingga risiko seperti bunuh diri (Reis \& Aron, 2008; Stack \& Scourfield, 2015). Penelitian ini dapat membantu pasangan untuk meningkatkan pemahaman terhadap kebutuhan individu atas cinta sehingga berdampak pula pada peningkatan kualitas hidup.

Hal lain yang perlu menjadi perhatian dalam kajian bahasa cinta adalah elemen waktu. Sebagai contoh, durasi suatu hubungan dapat berkontribusi pada kepuasan hubungan (Abe \& Oshio, 2018). Variabel hubungan romantis seperti kepuasan pernikahan umumnya tidak statis atau linear melainkan mengikuti pola kurva-linear (Hsiao, 2017). Penelitian kali ini telah menggambarkan ekspresi cinta dan perasaan dicintai pada satu periode waktu (cross-sectional). Penelitian bahasa cinta dengan pendekatan longitudinal dapat menggambarkan dengan lebih detil dinamika perubahan ekspresi cinta dan perasaan dicintai yang dialami oleh individu.

Implikasi praktis dari penelitian ini dan kaitannya dengan elemen waktu adalah kemampuan bahasa cinta untuk meningkatkan kualitas hubungan romantis. Sebagai contoh, pada pernikahan yang diatur (arranged marriage), relasi yang romantis bukanlah kondisi yang muncul sebelum pernikahan (Epstein, Pandit, \& Thakar, 2013). Bahasa cinta mampu menjadi faktor yang mendorong tumbuhnya relasi yang romantis. Hal ini semakin menunjukkan perlunya penelitian lanjutan yang menggambarkan relasi antara bahasa cinta, kepuasan hubungan, dan kaitannya terhadap durasi suatu hubungan.

Interaksi antara kedua aspek pasif dan aktif skala bahasa cinta menjadi sumber dukungan bukti empiris terhadap konsep bahasa cinta. Korelasi antara suatu alat ukur dengan alat ukur lainnya menjadi salah satu cara untuk menunjukkan kesahihan konstruk tersebut (Reeves \& Marbach-Ad, 2016). Hal ini telah ditunjukkan melalui penelitian sebelumnya yang menunjukkan hubungan antara bahasa cinta dan kepribadian (Surijah \& Sari, 2018). Studi kali ini menjadi sumber bukti empiris tambahan bagi pengembangan teori bahasa cinta.

Penelitian ini memiliki kelemahan yang menjadi pintu untuk penelitian lanjutan. Penelitian di masa mendatang dapat menguji faktor determinan yang menentukan terbentuknya bahasa cinta seseorang. Misalnya saja, sense of belonging seseorang ditentukan dari pengalaman masa kecil yang kebutuhan afeksi sosialnya tidak terpenuhi (Over, 2016). Kesejahteraan psikologis atau wellbeing menjadi suatu indikator implikasi dari kondisi tersebut (Over, 2016). Oleh karena itu, penelitian di masa mendatang dapat melihat pengaruh dari pengalaman masa kanak-kanak serta kesejahteraan psikologis sebagai variabel luaran.

Masukan lain yang dapat diberikan adalah terkait dengan penggunaan data 
yang diperoleh dari pasangan secara optimal. Partisipan penelitian ini adalah mahasiswa yang pernah/ sedang berada dalam relasi romantis. Penelitian di masa mendatang hendaknya menggunakan partisipan yang telah menikah atau partisipan yang berpasangan (suami-istri) sehingga data yang diperoleh dapat dianalisis menggunakan pendekatan actorpartner interdependent model (Hadden, Baker, \& Knee, 2018; Maroufizadeh, Hosseini, Foroushani, Omani-Samani, \& Amini, 2019).

Penelitian bahasa cinta di masa mendatang juga perlu memerhatikan faktor gender atau jenis kelamin dalam memahami perasaan dicintai. Penelitian terdahulu menunjukkan bahwa laki-laki dan perempuan memiliki ekspresi afeksi yang berbeda (Schoenfeld, Bredow, \& Huston, 2012). Penelitian ini belum memilah data yang diperoleh dari partisipan laki-laki dan perempuan. Penelitian selanjutnya dapat melakukan analisis multilevel (Clark, 2017) untuk melihat peranan jenis kelamin terhadap hubungan antara bahasa cinta pasif dan aktif.

\section{Simpulan}

Bahasa cinta berbeda dengan konsep tipologi cinta lain yang umumnya menggambarkan kondisi relasi romantis yang dialami seperti relasi yang penuh komitmen atau relasi yang intim. Bahasa cinta mengungkap hal-hal yang membuat seseorang merasa dicintai. Simpulan penelitian ini adalah individu yang merasa dicintai dengan suatu cara tertentu relatif akan menunjukkan rasa cintanya dengan cara yang sama. Seseorang dengan tendensi FLL receiving gift (menerima hadiah) juga cenderung akan menunjukkan perasaannya dengan memberikan hadiah. Contoh yang lain, seseorang yang merasa dicintai saat menerima pujian juga akan cenderung mengekspresikan perasaannya secara verbal (words of affirmation). Bagi pasangan dan praktisi konseling pasangan, temuan ini membantu memahami dan memenuhi kebutuhan untuk merasa dicintai.

Simpulan lain yang didapat dari penelitian ini adalah berkaitan dengan sumber bukti empiris. Kendati penelitan terdahulu belum mendapatkan hasil analisis faktor yang konvergen dengan lima aspek awal FLL, studi kali ini menunjukkan bahwa bahasa cinta seseorang dapat diprediksi dari cara seseorang menunjukkan perasaannya. Relasi antara kedua konsep tersebut menjadi suatu sumber bukti pendukung validasi konsep bahasa cinta walau studi lebih lanjut di masa mendatang masih dibutuhkan.

\section{Daftar Pustaka}

Abe, S., \& Oshio, A. (2018). Does marital duration moderate (dis)similarity effects of personality on marital satisfaction? SAGE Open. doi.org/10.1177/2158244018784985

Askarpour, A., \& Mohammadipour, M. (2016). Psychometric properties of Sternberg love scale. Journal of Fundamental and Applied Sciences, $8(4)$, 2036-2046. doi.org/10.4314/jfas.v8i2s.164

Bartholomew, K. (1990). Avoidance of intimacy: An attachment perspective. Journal of Social and Personal Relationships, 7, 147-178.

Bringle, R. G., Winnick, T., \& Rydell, R. J. (2013). The prevalence and nature of unrequited love. SAGE Open, 1-15. doi.org/10.1177/2158244013492160

Brown, T. (2009). Construct validity: A unitary concept for occupational therapy assessment and measurement. Hong Kong Journal of Occupational Therapy, 20(1), 30-42. doi.org/10.1016/S15691861(10)700565

Burton, N. (2017). The 7 types of love. Retrieved August 28, from https://themindsjournal.com/the-7types-of-love/

Clark, A. (2017). Updating the gender gap(s): A multilevel approach to what 
underpins changing cultural attitudes. Politics \& Gender, 13(1), 26-56. doi:10.1017/S1743923X16000520

Cook, M., Pasley, J., Pellarin, E., Medow, K., Baltz, M., \& Buhman-Wiggs, A. (2013). Construct validation of the five love languages. Journal of Psychological Inquiry, 18(2), 50-61.

D’Arienzo, M. C., Boursier, V., \& Griffiths, M. D. (2019). Addiction to social media and attachment styles: A systematic literature review. International Journal of Mental Health and Addiction (2019). doi.org/10.1007/s11469-019-00082-5

Egbert, N., \& Polk, D. (2006). Speaking the language of relational maintenance: A validity test of Chapman's (1992) five love languages. Communication Research Reports, 23(1), 19-26.

Epstein, R., Pandit, M., \& Thakar, M. (2013). How love emerges in arranged marriages: Two cross-cultural studies. Journal of Comparative Family Studies, 44(3), 341-360. Retrieved from http://www.jstor.org/stable/23644606

Gana, K., Saada, Y., \& Untas, A. (2013). Effects of love styles on marital satisfaction in heterosexual couples: A dyadic approach. Marriage \& Family Review, 49(8), 754-772. doi: 10.1080/01494929.2013.834025

Gao, Z., Gao, S., Xu, L., Zheng, X., Ma, X., Luo, L. \& Kendrick, K. M. (2017). Women prefer men who use metaphorical language when paying compliments in a romantic context. Scientific Reports, doi.org/10.1038/srep40871

Gaunt, R. (2006). Couple similarity and marital satisfaction: Are similar spouses happier? Journal of Personality, 74(5), 1401-1420. doi: 10.1111/j.1467-6494.2006.00414.x

Gosling, S. D., Rentfrow, J. R., \& Swann Jr., W. B. (2003). A very brief measure of big-five personality domains.
Journal of Research in Personality, 37, 504-528.

Grant-Jacob, J. A. (2016). Love at first sight. Frontiers in Psychology, 7, 1113. doi:10.3389/fpsyg.2016.01113

Großmann, I., Hottung, A., \& KrohnGrimberghe, A. (2019) Machine learning meets partner matching: Predicting the future relationship quality based on personality traits. PLOS ONE, 14(3), e0213569. doi.org/10.1371/journal.pone.0213569

Guthrie, M. F., Marshall, P. H., Hendrick, S. S., Hendrick, C., \& Logue, E. (2018). Human love styles and attitudes toward pets, Anthrozoös, 31(1), 41-60. doi.org/10.1080/08927936.2018.14062 00

Hadden, B. W., Baker, Z. G., \& Knee, C. R. (2018). Let it go: Relationship autonomy predicts pro-relationship responses to partner transgressions. Journal of Personality, 86, 868-887. doi.org/10.1111/jopy.12362

Hazan, C., \& Shaver, P. (1987). Romantic love conceptualized as an attachment process. Journal of Personality and Social Psychology, 52, 511-524.

Hendrick, C., \& Hendrick, S. (1986). A theory and method of love. Journal of Personality and Social Psychology, 50, 392-402.

Hendrick, C., \& Hendrick, S. (1989). Research on love: Does it measure up? Journal of Personality and Social Psychology, 56(5), 784-794.

Hsiao, Y.-L. (2017) Longitudinal changes in marital satisfaction during middle age in Taiwan. Asian Journal of Social Psychology, 20, 22-32. doi: 10.1111/ajsp.12161.

Jin, W., Xiang, Y., \& Lei, M. (2017). The deeper the love, the deeper the hate. Frontiers in Psychology, 8, 1940. doi: 10.3389/fpsyg.2017.01940

Jung, C. G. (1971). Psychological types. Dalam G. Adler \& R. F. C. Hull (Eds.), The collected works of $C$. G. Jung: 
Complete digital edition (6th ed.). Princeton, NJ: Princeton University Press.

Kiecolt-Glaser, J. K., \& Wilson, S. J. (2017). Lovesick: How couples' relationships influence health. Annual Review of Clinical Psychology, 13, 421-443. doi:10.1146/annurev-clinpsy032816-045111

Langeslag, S. J. E., \& van Strien, J. W. (2016). Regulation of romantic love feelings: Preconceptions, strategies, and feasibility. PLOS ONE, 11(8), e0161087.

doi.org/10.1371/journal.pone.0161087

Lee, J. A. (1977). A typology of styles of loving. Personality and Social Psychology Bulletin, 3(2), 173-182. doi.org/10.1177/014616727700300204

Levy, M. B., \& Davis, K. E. (1988). Love styles and attachment styles compared: Their relations to each other and to various relationship characteristics. Journal of Social and Personal Relationships, 5(4), 439-471. doi.org/10.1177/0265407588054004

Lomas, T. (2018). The flavours of love: A cross-cultural lexical analysis. Journal for the Theory of Social Behaviour, 48, 134-152. doi.org/10.1111/jtsb.12158

Maroufizadeh, S., Hosseini, M., Foroushani, A. R., Omani-Samani, R., \& Amini, P. (2019). The relationship between perceived stress and marital satisfaction in couples with infertility: Actor-partner interdependence model. International Journal of Fertility \& Sterility, 13(1), 66-71. doi:10.22074/ijfs.2019.5437

Martínez-Mesa, J., González-Chica, D. A., Bastos, J. L., Bonamigo, R. R., \& Duquia, R. P. (2014). Sample size: How many participants do I need in my research? Anais Brasileiros de Dermatologia, 89(4), 609-615. doi.org/10.1590/abd18064841.20143705

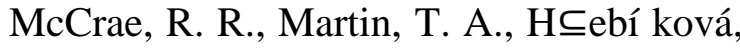
M., Urbánek, T., Boomsma, D. I.,
Willemsen, G., \& Costa, P. T. (2008). Personality trait similarity between spouses in four cultures. Journal of Personality, 76(5), 1137-1164. doi.org/10.1111/j.14676494.2008.00517.x

Over, H. (2016). The origins of belonging: Social motivation in infants and young children. Philosophical Transactions of the Royal Society of London. Series B, Biological sciences, 371(1686), 20150072. doi:10.1098/rstb.2015.0072

Polk, D. M., \& Egbert, N. (2013). Speaking the languages of love: On whether Chapman's (1992) claims stand up to empirical testing. The Open Communication Journal, 7, 1-11.

Reeves, T. D., \& Marbach-Ad, G. (2016). Contemporary test validity in theory and practice: A primer for disciplinebased education researchers. CBE Life Sciences Education, 15(1), rm1. doi:10.1187/cbe.15-08-0183

Read, D. L., Clark, G. I., Rock, A. J., \& Coventry, W. L. (2018). Adult attachment and social anxiety: The mediating role of emotion regulation strategies. PLOS ONE, 13(12), e0207514. DOI: doi.org/10.1371/journal.pone.0207514

Reis, H. T., \& Aron, A. (2008). Love: What is it, why does it matter, and how does it operate? Perspectives on Psychological Science, 3(1), 80-86. doi.org/10.1111/j.17456916.2008.00065.x

Reizer, A. (2015). Influence of employees' attachment styles on their life satisfaction as mediated by job satisfaction and burnout. The Journal of Psychology, 149(4), 356-377, doi: 10.1080/00223980.2014.881312

Rubin, Z. (1970). Measurement of romantic love. Journal of Personality and Social Psychology, 16, 265-273.

Saggino, A., Martino, M., Balsamo, M., Carlucci, L., Ebisch, S., Innamorati, M., Picconi, L., Romanelli, R., Sergi, M. R., \& Tomassi, M. (2016). 
Compatibility quotient, and its relationship with marital satisfaction and personality traits in Italian married couples. Sexual and Relationship Therapy, 31(1), 83-94. doi: 10.1080/14681994.2015.1070952

Schoenfeld, E. A., Bredow, C. A., \& Huston, T. L. (2012). Do men and women show love differently in marriage? Personality and Social Psychology Bulletin, 38(11), 13961409. doi.org/10.1177/0146167212450739

Simpson, J. A., \& Rholes, W. S. (2017). Adult attachment, stress, and romantic relationships. Current Opinion in Psychology, 13, 19-24. doi:10.1016/j.copsyc.2016.04.006

Spörrle, M., \& Bekk, M. (2014). Metaanalytic guidelines for evaluating single-item reliabilities of personality instruments. Assessment, 21(3), 27285.

Stack, S., \& Scourfield, J. (2015). Recency of divorce, depression, and suicide risk. Journal of Family Issues, 36(6), 695-715. doi.org/10.1177/0192513X13494824

Sternberg, R. J. (1986). A triangular theory of love. Psychological Review, 93(2), 119-135.

Sternberg, R. J. (1997). Construct validation of a triangular love scale. European Journal of Social Psychology, 27, 313-335.

Surcinelli, P., Rossi, N., Montebarocci, O., \& Baldaro, B. (2010). Adult attachment styles and psychological disease: Examining the mediating role of personality traits. The Journal of Psychology, 144(6), 523-534. doi: 10.1080/00223980.2010.508082

Surijah, E. A., \& Kirana, C. T. (in press). Five love languages scale factor analysis. Makara: Human Behavior Studies in Asia.

Surijah, E. A., \& Sari, K. (2018). Five love languages and personality factor revisited. Anima Indonesian
Psychological Journal, 33(2), 71-87, doi.org/10.24123/aipj.v33i2.1579

Surijah, E. A., \& Septiarly, Y. L. (2016). Construct validation of five love languages. Anima Indonesian Psychological Journal, 31(2), 65-76. doi.org/10.24123/aipj.v31i2.565

Tartakovsky, M. (2015). Nourishing the different types of intimacy in your relationship. Retrieved August 28, 2018 from https://psychcentral.com/blog/nourishi ng-the-different-types-of-intimacy-inyour-relationship/

Unk, I. (2017). A psychological map of love. Alain de Botton's love stories as reflections of Sternberg's theory on love. [sic] - a Journal of Literature, Culture and Literary Translation, 2, 115. doi: 10.15291/sic/2.7.lc.2

Wang, S., Kim, K., \& Boerner, K. (2018). Personality similarity and marital quality among couples in later life. Personal Relationships, 25, 565-580. doi.org/10.1111/pere.12260

Weisskirch, R. S. (2017). Abilities in romantic relationships and well-being among emerging adults. Marriage \& Family Review, 53(1), 36-47. 10.1080/01494929.2016.1195471

Wilson, G., \& Cousins, J. (2003). Partner similarity and relationship satisfaction: Development of a compatibility quotient. Sexual and Relationship Therapy, 18(2), 161-170. 10.1080/1468199031000099424

Yang, X., Mak, W. W. S., Ho, C. Y. Y., \& Chidgey, A. (2017). Self-in-love versus self-in-stigma: Implications of relationship quality and love attitudes on self-stigma and mental health among HIV-positive men having sex with men. AIDS Care, 29(1), 132-136. 10.1080/09540121.2016.1200714

Zeng, X., Pan, Y., Zhou, H., Yu, S., \& Liu, $X$. (2016). Exploring different patterns of love attitudes among Chinese college students. PLoS ONE, 11(11), 
Psympathic, Jurnal Ilmiah Psikologi Juni 2019, Vol. 6, No. 1, Hal. : 1-14

e0166410.

doi.org/10.1371/journal.pone.0166410 